\title{
The Introduction of Service Fees by Travel Agencies: A Case Study in Bloemfontein
}

\section{A J Strydom}

School of Tourism, Hospitality and Sport, Technikon Free State

\section{ABSTRACT}

Travel agencies normally receive commission from airlines, tour operators, accommodation establishments and car hire companies in exchange for bookings. Global trends in this commission structure indicate dramatic changes, especially regarding airlines. The majority of them have introduced a system of commission capping, whereby commission paid to travel agencies has been reduced and expectations are that it might even become zero in future. Against this background, travel agencies are considering introducing a system of service fees. It implies that clients will have to pay for services such as the preparation of quotations for national and/or international holidays or business trips. This paper discusses the results of research that was undertaken amongst the middle to higher income classes of the residents of Bloemfontein regarding the introduction of service fees by travel agencies.

JEL L90

\section{INTRODUCTION}

Travel and tourism is a vast, complex network of business which may include activities and travel carried out for leisure, family or business reasons, and usually has the following purposes: rest, entertainment, conducting business and/or personal development (Elliot, 1997: 4).

According to Geldenhuys (2000: 1) travel (and tourism) has existed since time immemorial. The global travel and tourism industry has developed rapidly since World War 11 and is currently regarded as one of the fastest growing industries in the world (Van Niekerk, 1997: 1; Buhalis, 2003). According to the World Tourism Organisation (WTO, 2001) almost 715 million international tourist arrivals were registered in 2002, compared to 25 million in 1950.

Tourism to and from South Africa also experienced rapid expansion in the recent past. According to South African Tourism (Satour, 2002) total international arrivals (Africa included) to South Africa increased by 70 percent 
between 1994 and 1999. Also, the total number of South African citizens (334 509) who "departed" temporarily during March 2002, increased by 16,4 percent compared to the same period of 2001 (SSA, 2003).

The latter figure constitutes one of the major sources of a travel agency's income in the form of commission. There is a worldwide trend by airlines to cut travel agencies' commissions, and it seems as if it may even drop to zero in future. According to Feldman (2002: 62) the American Society of Travel Agents reported that the average base commission rate declined from a high of 11,8 percent in 1994 to 6,24 percent in 2001, while domestic base commissions have been eliminated entirely. Kiesnoski (2002: 4) and Milligan (2002: 8) confirm this tendency, and the latter is of opinion that it coincides with the growth of sales via the Internet (also compare Travel Weekly, 2003: 4). Personal interviews with ASATA (Association of Southern African Travel Agents) members in Bloemfontein confirmed that the commission structure has undergone dramatic changes, especially with regard to airlines. The majority of them introduced a system of commission capping, whereby commission to travel agencies has been reduced, and expectations are that it might even become zero in future.

As a result, it is imperative that travel agencies restructure their revenue base through the introduction of service fees. This implies that clients will have to pay for services like the preparation of quotations for national and/or international holidays or business trips, booking of air tickets, issuing of visas and hotel reservations. The argument is that a client should pay for a professional service consultation at a travel agency, in the same way as he or she would for the medical profession, for instance.

Although service fee models have been implemented at several international and national travel agencies (Successful Meetings, 2002: 36; Feldman, 2002: 62), they are still a relatively new and untapped concept in parts of South Africa.

Against the above-mentioned background, the purpose of this article is to discuss the results of research that was undertaken amongst the middle to higher income classes of residents of Bloemfontein regarding the introduction of service fees by travel agencies. This includes their willingness to pay for professional travel services, as well as the amount payable and types of services that should be subjected to service fees. 


\section{OBJECTIVES}

The objectives of this article are to discuss the results of research undertaken amongst middle to higher income residents of certain suburbs in Bloemfontein regarding their awareness (as clients) and perception of the introduction of service fees. Would they be willing to pay for professional travel services, as this was an inevitable way to ensure a sustainable income to the travel industry. An additional objective was to identify what services should be subjected to service fees and to determine suitable fees for delivering these professional services by travel agencies.

The research is applicable in two ways: it gives an indication of local market reactions to the introduction of service fees, and it can be used as a point of departure by travel agencies in other regions of South Africa who also want to introduce this system in an environment where income sources are decreasing. Specific amounts and preferences may differ according to macro-environmental variables such as income levels, needs and personal taste.

\section{RESEARCH METHODOLOGY}

The research was undertaken in Bloemfontein during June 2002. Two suburbs were targeted, namely Universitas, representing the middle class tourist, and Waverley, representing the higher-class tourist.

A nine percent (243 out of a possible 2666 households) sample was determined in the abovementioned suburbs and information was collected through personal interviews by means of a structured questionnaire. The questionnaire was compiled from inputs received from all the ASATA-travel agencies in Bloemfontein, regarding their research needs regarding the introduction of service fees and related components, as described in the objectives of this article.

A 90 percent (220 correctly completed questionnaires) response rate was obtained.

\section{LIMITATIONS OF THE STUDY}

The study focused on middle to higher income residents of two suburbs in Bloemfontein. Lower income categories and townships were not included. Only houses were included in the sample and no town houses, flats or other forms of 
residence. The research results only reflect the views of a specific section of the general public and not the corporate market of Bloemfontein.

\section{RESEARCH RESULTS}

\section{Theoretical analysis: Recent changes in travel retailing}

Lubbe (2000: 39-45) indicates the following areas as having the biggest impact on the way in which travel is distributed in South Africa in the past three years:

- Deregulation of the airline industry. This factor increased competition and led to declining yields amongst airlines. From the airlines' point of view the deregulation brought about several changes such as:

- The formulation of alliances - According to Lubbe (2000: 40) the aim of alliances is "mainly to extend the market reach of airlines, controlling costs, and possibly limiting competition in the global transport sector. These alliances include collaborative pacts from equity stakes to code-sharing agreements, joint services, block seat or block booking arrangements, joint marketing agreements, joint fares and franchise agreements". These alliances caused changes in ticket distribution methods and affect the retail travel industry in terms of preferred supplier relationships and revenue.

- Lower distribution costs - Airlines are continuously looking for ways to offset declining profit margins. This resulted in the implementation of a system of commission capping, whereby commission rates to travel agencies were decreased, with a consequent loss in revenue for the latter party (compare Milligan, 2002: 8; Kiesnoski, 2002: 4; Feldman, 2002: 62).

- In-house reservations - Some airlines allow clients to book directly through their own in-house reservations systems. The result is a lack of potential income to travel agencies.

- Airline loyalty programmes - Frequent flyer programmes such as the Voyager Mile Programme of South African Airways (SAA) tend to motivate clients to book directly with the airline at the cost of the local travel agent (Lewis and Talalayevsky as in Lubbe, 2000: 41).

- $\quad$ Technological advancements - The following two technological advancements are, amongst others, dominant on the travel retail scene:

- The Internet - As more people become computer literate, clients do their own travel bookings via the Internet, with a consequent loss of income to travel agencies. 
- Electronic ticketing - SAA recently introduced a system of electronic ticketing whereby travellers are offered the option of booking flights without tickets. The airline seats are sold directly to the clients by the airlines.

- $\quad$ Changes in consumer demands - Lubbe (2000: 47) indicates major changes between "new" and "old" tourists in the sense that: "new tourists are more experienced, more environmentally aware, more independent, more flexible, more quality conscious and harder to please than before”. One way in which travel agencies reacted in this regard was to restructure their revenue-base with a move towards the introduction of service-fee models in an attempt to become an agent for the client instead of the travel provider. Joselyn (as in Lubbe, 2000: 51) proposes three types of fees to be charged by travel agencies in future:

- Professional fees in exchange for experience and expertise;

- Penalty fees in cases where work needs to be redone;

- Service fees for performing services for which inadequate revenue is anticipated.

A more detailed analysis of the types of fees to be charged by travel agencies is provided in a journal called Successful Meetings (2002: 36). According to this journal, service fees may be charged by travel agencies in the following instances:

- $\quad$ Provision of all travel and airfare possibilities;

- $\quad$ Reissuing of tickets at cheaper prices;

- $\quad$ Cancellation of travel arrangements;

- Explanation of travel restrictions and security requirements to clients;

- $\quad$ Recommendation of good accommodation and restaurants;

- $\quad$ Availability during trips via telephone as well as after-hour availability for emergency purposes.

\section{Empirical research results: Demographic statistics}

The demographic statistics of the respondents are as follows:

- $\quad$ Just over half the respondents (52 percent) were males.

- $\quad$ The majority (29 percent) of the respondents are in the age category 36 to 45 years old and form part of a family consisting of three to four members (54 percent).

- $\quad$ Almost three-quarters (73 percent) of all respondents are married.

- $\quad$ The average monthly gross income per household differs substantially between the middle class (Universitas) and higher class (Waverley) 
suburbs. In Universitas, the majority of households (50 percent) earn between R6 000 and R12 000 per month, whereas in Waverley 60 percent of households earn above R12 000 per month.

\section{The introduction of service fees in Bloemfontein}

Research results revealed that:

- In both suburbs husbands predominantly pay for holidays.

- $\quad$ More than half (56 percent) of the respondents use the services of travel agencies once or more times a year.

- $\quad$ All respondents accepted the fact that they have to pay for professional services rendered by a medical practitioner or lawyer.

- $\quad$ Almost 80 percent of the respondents also agreed that professional travel advice by a qualified travel agent is essential when they plan to travel.

- More than 80 percent of the respondents are prepared to pay for professional advice from travel agencies, although less than a quarter of them were aware of the possible introduction of such a system by travel agencies in Bloemfontein.

\section{Services at travel agencies for which a service fee may be charged}

Figure 1 sets out services for which a service fee may be charged.

Figure 1 Services to be included in a service fee model

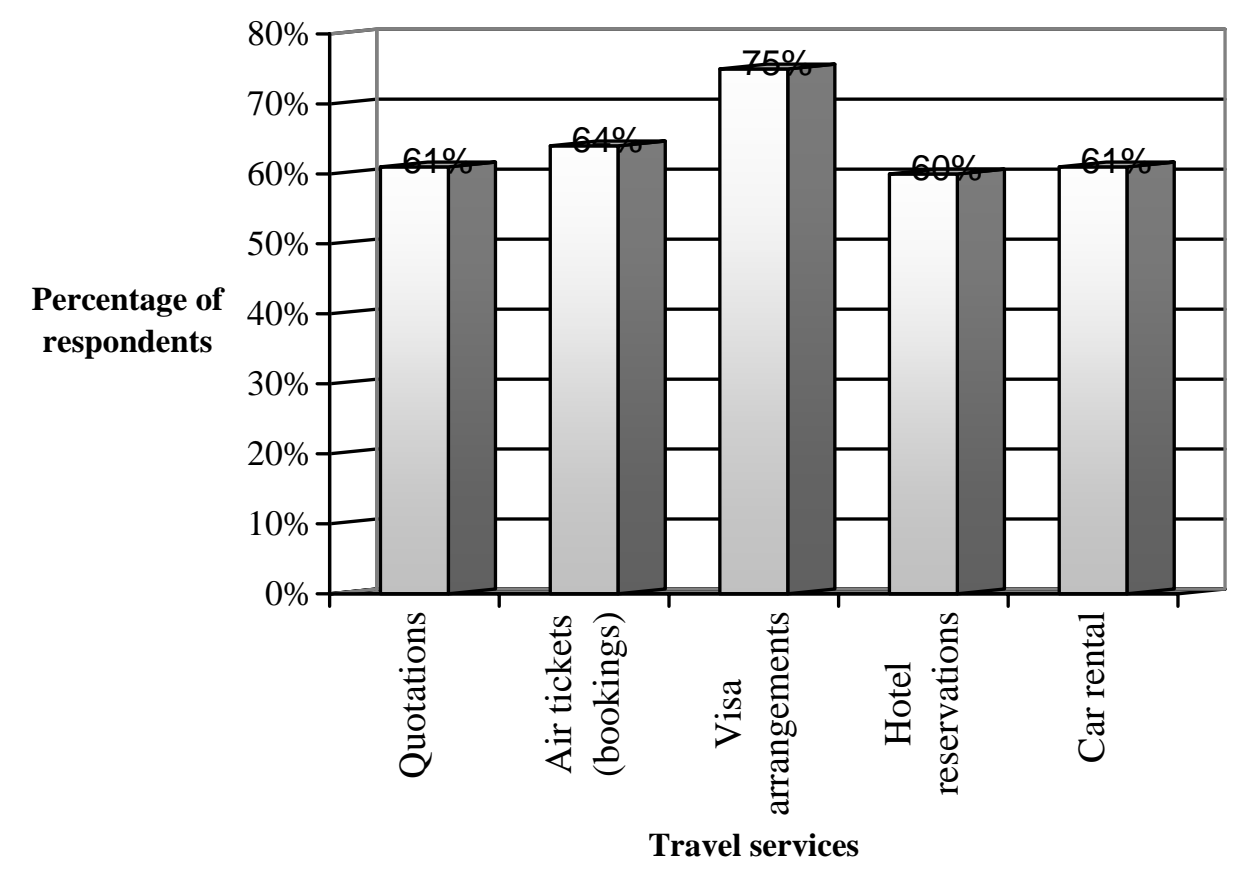


It is evident from Figure 1 that the majority of respondents from both suburbs agreed that service fees may be charged for the following services (based on personal preferences):

- A complete quotation of travel costs (61 percent). It is interesting to note that only 41 percent of the respondents in Waverley agreed to this, while the majority of respondents in Universitas (65 percent) are willing to pay for travel quotations;

- $\quad$ Booking of air tickets (64 percent);

- $\quad$ Issuing of visas (75 percent);

- $\quad$ Hotel reservations (60 percent);

- $\quad$ Car Rental (61 percent)

The suggested amounts to be charged for the services mentioned in Figure 1, are shown in Figure 2. Please note that the results in Figure 2 are based on service fees related to national travel arrangements.

\section{Figure 2 Service fees for national travel arrangements}

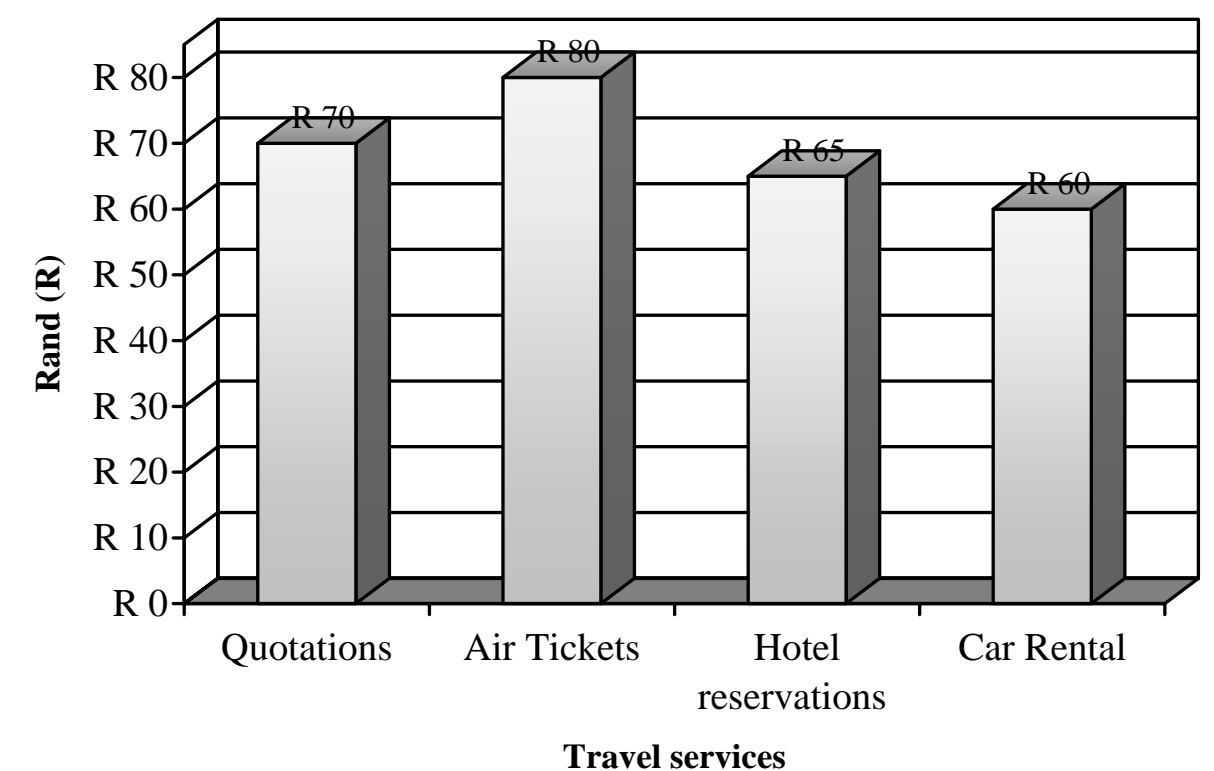

Travel services

From Figure 2 it is clear that the highest service fee should be apportioned to booking of air tickets, and the lowest to booking car rental services by a travel agency. Current average service fees charged by travel agencies in Bloemfontein represent approximately 1,5 percent of total travel costs, compared to the 3.0 percent suggested by respondents in this research study. 
The suggested amounts for services to be rendered with regard to international travel, are indicated in Figure 3.

The highest service fee may be awarded to the issuing of visas, while the lowest fee, as in the case of Figure 2, may be charged for organising car rental services. Current average service fees charged by travel agencies in Bloemfontein represent approximately 0,5 percent of total travel costs, compared to the 2.3 percent suggested by respondents in this research study. Service fees are still far lower than amounts of commission received by travel agencies, and the introduction thereof is only an attempt to fill the gap between previous (between 10 and 15 percent) and current levels (9 percent) of commission.

\section{Figure 3 Service fees for international travel arrangements}

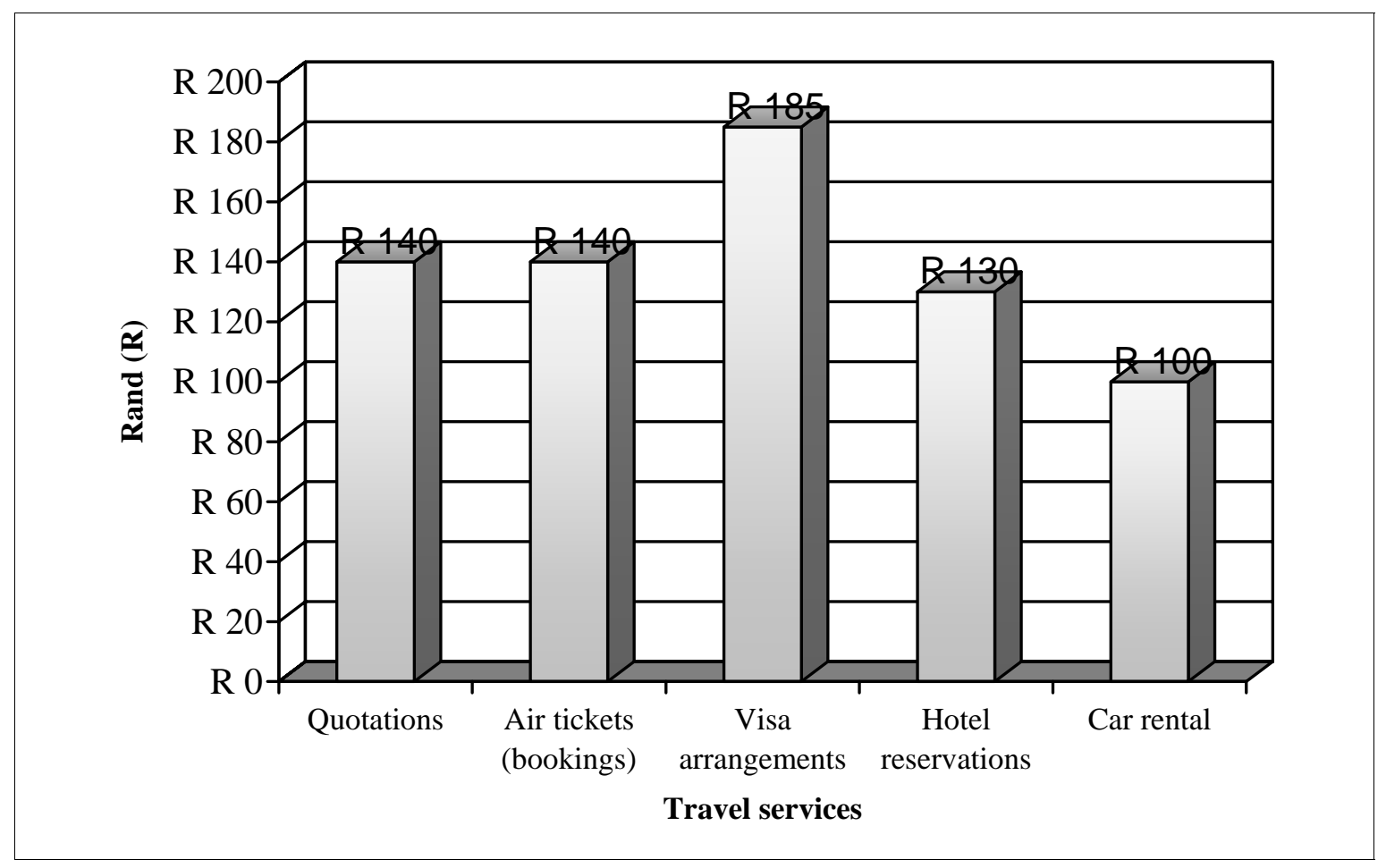

\section{Services that should be excluded from service fees}

The majority of respondents in both suburbs indicated (based on personal preferences) that service fees should not be charged for the following services rendered by travel agencies:

- The provision of additional information on tourism destinations (69 percent);

- $\quad$ Issuing of free voyager tickets (76 percent). 


\section{Services for which the introduction of service fees may be considered}

The research results from both suburbs did not give a clear indication on the possible introduction of service fees with regard to the services, indicated in Figure 4.

Figure 4 Services to consider for inclusion in a service fee model

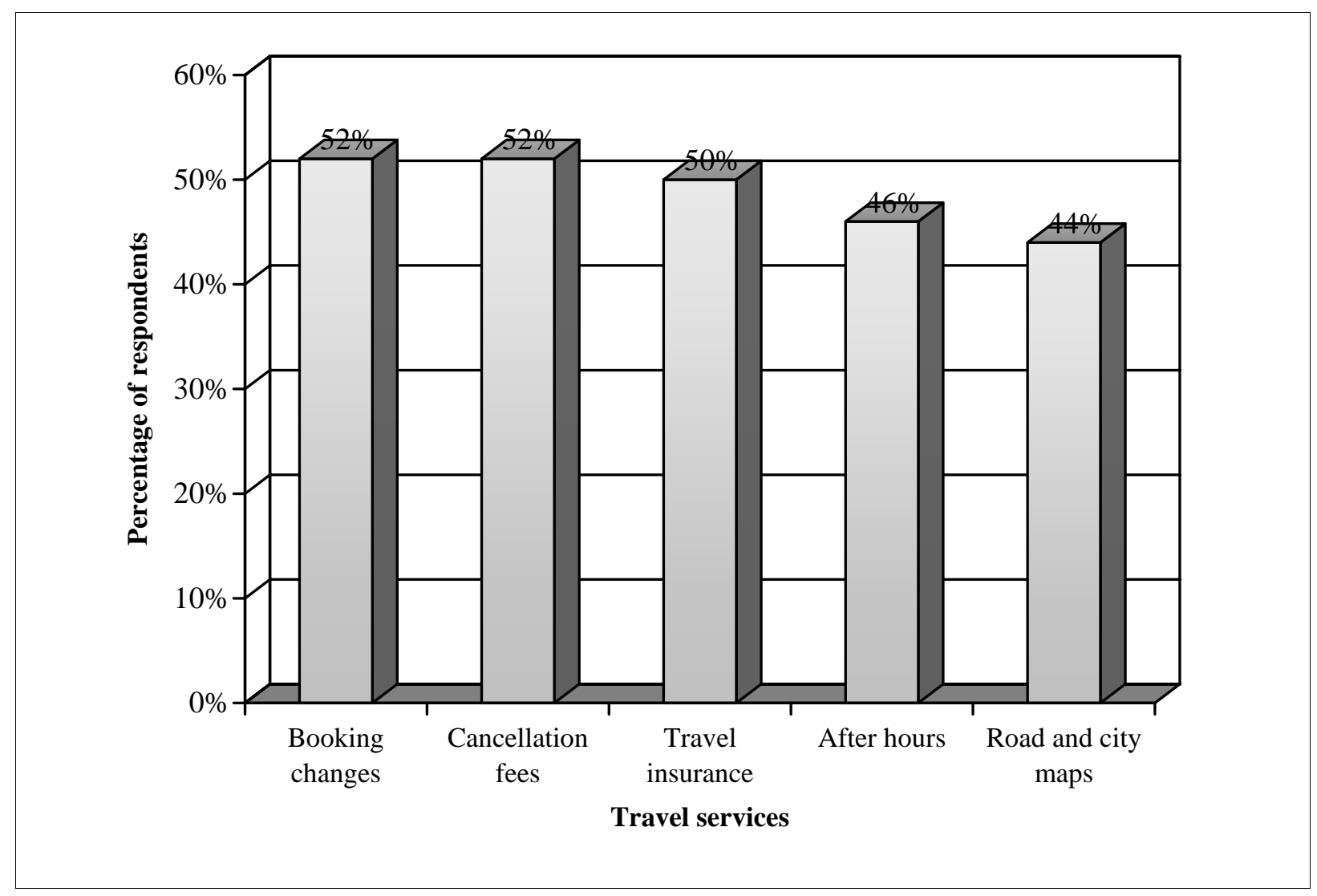

Figure 4 shows that respondents made no clear distinction between services included in a service fee scenario:

- Changes of bookings (52 percent yes);

- Cancellation of reservations (52 percent yes);

- Travel insurance (50 percent yes).

- It is interesting to note that 68 percent of the respondents in Waverley agreed on the introduction of service fees regarding the organisation of travel insurance by the travel agent on behalf of the tourist.

- After hours consultation and reservations (46 percent yes);

- The provision of detailed road and city maps (44 percent yes).

If travel agencies do consider the implementation of service fees on the services mentioned in Figure 4, it could be considered according to the suggested 
amounts as outlined in Figure 5. Please take note that Figure 5 is based on national travel arrangements.

Figure 5 Suggested service fees (national travel)

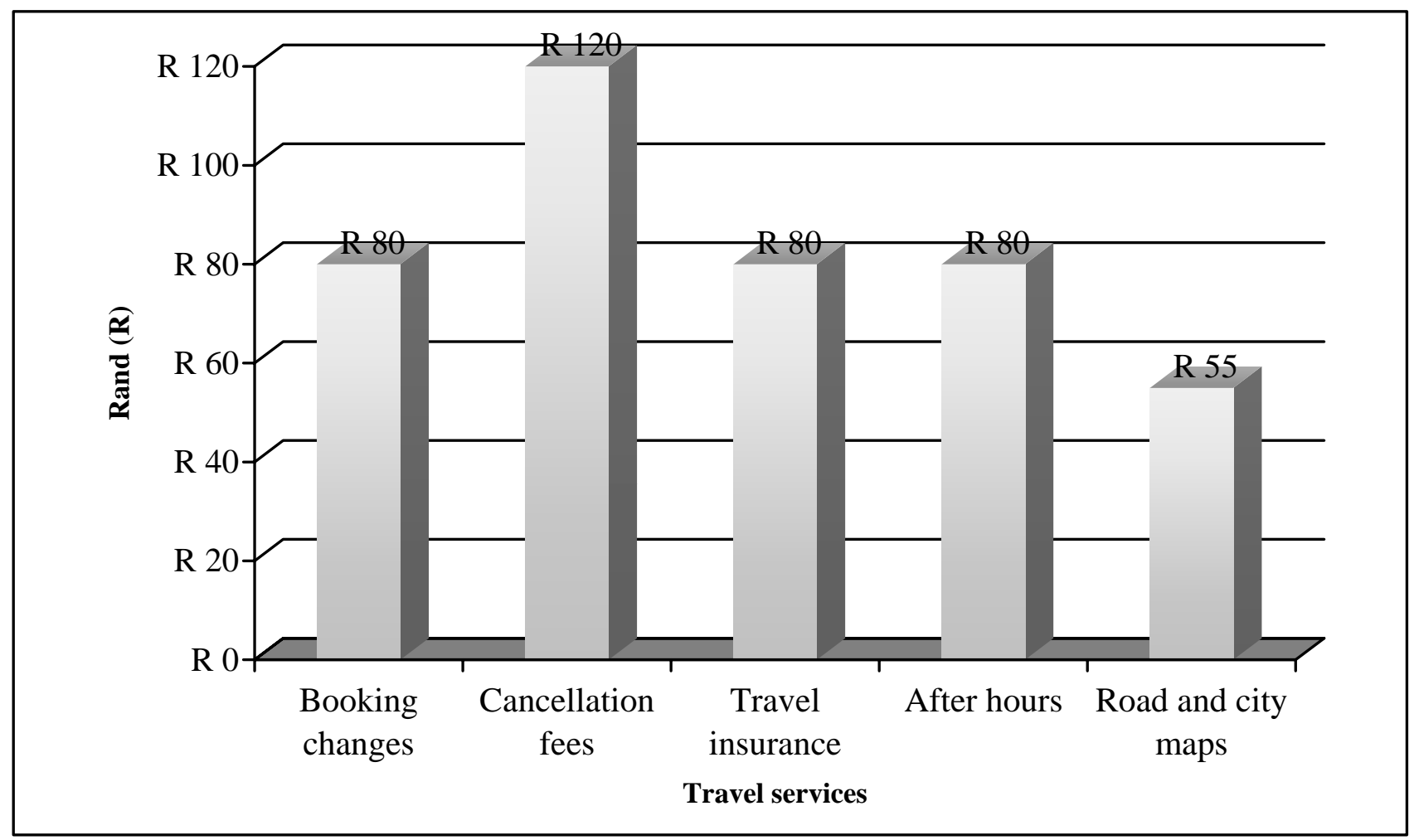

The most interesting deduction from Figure 5 is that respondents consider the cancellation of travel arrangements a huge burden to travel agencies and feel they are entitled to a substantial service fee in such cases (R 120).

The suggested amounts of service fees in the case of international travel, are indicated in Figure 6.

As in Figure 5, a relatively high fee is proposed in the case of cancellation of travel arrangements. The respondents proposed the same fee when international travel insurance is organised by a travel agency.

\section{Research results from respondents who made use of services of travel agencies in the past year}

As mentioned earlier in this document, just more than half of all respondents (56 percent) make use of travel agencies at least once a year. It was decided to analyse the results of these respondents as a method of check-and-balance against the overall results. The assumption is that these respondents have a better understanding and knowledge of travel agency operations and may be in a 
better position to supply information on service fees. The results showed exactly the same tendencies and even suggested specific amounts to be charged for certain services, with the following exceptions:

- Cancellation of client reservations

- Travel insurance.

Figure 6 Suggested service fees (international travel)

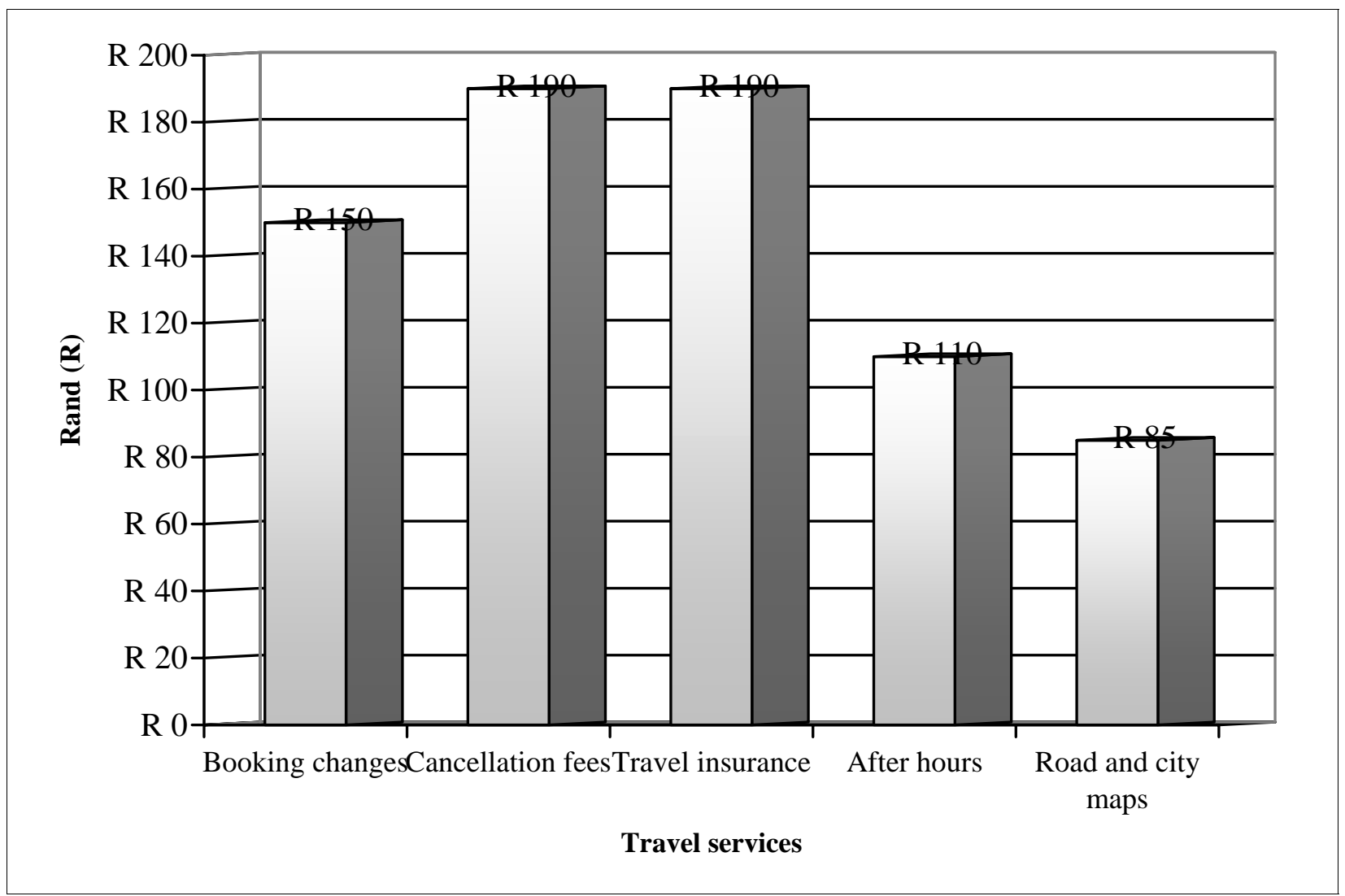

More than 60 percent of the respondents in both suburbs indicate a willingness to pay for the above-mentioned services. Even the suggested fees (compare figures 5 and 6) are also applicable in this regard.

\section{CONCLUSION AND RECOMMENDATIONS}

It is evident from the research that travel agencies in South Africa may consider the introduction of service fees as a future option to expand their income bases.

It is also clear from the empirical research that the target population in Bloemfontein is in principle willing to pay service fees for particular professional services from travel agencies. Travel agencies in Bloemfontein who already introduced service fees, currently charge lower fees than the recommended fees of this research study. Therefore, the research results should 
be used as a guideline for travel agencies over the medium to longer term, especially when further reductions in commission structures from airlines take place again.

It is interesting to note that the travel agencies in Bloemfontein charge basically the same service fee for international and domestic travel, while the research indicated a willingness by respondents to pay substantially more in the case of international travel. A similar approach may be considered by travel agencies.

More research amongst a wider variety of clients is necessary before specific service categories mentioned in Figure 4 are considered as a definite option. The research results regarding respondents who made use of travel services in the past year may, however, convince managers of travel agencies to include travel insurance and cancellation of client reservations amongst the services for which a service fee may be charged.

\section{REFERENCES}

1 BUHALIS, D. (2003) E-Tourism - Information Technology for Strategic Tourism Management, Pearson Education Limited: United Kingdom.

2 ELliOTT, J. (1997) Tourism: Politics and Public Sector Management, Routledge: New York.

3 FELDMAN, J.M. (2002) "Changing the rules. Air transport world”, 39 (10): 62, Ebscohost http://search.epnet.com. Downloaded: 2003-10-11.

4 GELDENHUYS, S. (2000) "Career profiles for the travel sector of the tourism industry”, M Com-dissertation. Potchefstroom University for Christian Higher Education.

5 KIESNOSKI, K. (2002) "Finnair cuts retailers pay to 5\%, no cap", Travel Weekly, 61 (37): 4, Ebscohost: http://weblinks2.epnet.com. Downloaded 2003-11-30.

6 LUBBE, B. (2000) Tourism Distribution: Managing the Travel Intermediary, Juta: Cape Town.

7 MILLIGAN, M. 2002. Amtrak ends agent pay on several services. Travel Weekly, 61 (46): 8, Ebscohost: http://search.epnet.com. Downloaded: 2003-11-06.

8 SATOUR see South African Tourism.

9 SOUTH AFRICAN TOURISM (2002) http//www.satour.com. Downloaded: 2003-03-28.

10 STATISTICS SOUTH AFRICA. (2003) http//www.statssa.gov.za. Downloaded: 2003-02-12.

11 SUCCESSFUL MEETINGS (2002) VNU eMedia Inc., 51(9): 36, August. Ebscohost http://search.epnet.com. Downloaded: 2003-11-10. 
12 TRAVEL WEEKLY (2002) NorthStar Travel Media, LLC \& Thomson Gail Group, 62(20): 4, Ebscohost http://search.epnet.com. Downloaded: 2003-11-06.

13 VAN NIEKERK, M. (1997) "Development of a core curriculum on tourism as an ACE secondary school subject", MA-dissertation. Potchefstroom University for Christian Higher Education.

14 WORLD TOURISM ORGANISATION (2001) http://world-tourism.org/ newsroom/Releases/2003/jan/numbers2002.htm. Downloaded: 2003-0518. 